22 Office of Population Censuses and Surveys, Cancer Incidence in Great Britain, 1963-1966, p. 18. London, HMSO, 1972.

${ }^{23}$ American Society of Anesthesiologists, Anesthesiology, 1974, 41, 321.

${ }^{24}$ Office of Population Censuses and Surveys, Cancer Incidence in Great Britain, 1963-1966, p.14. London, HMSO, 1972.

25 Bruce, D L, et al, Anesthesiology, 1974, 41, 71.

${ }^{26}$ Bruce, D L, et al, Anesthesiology, 1968, 29, 565.

27 Doll, R, and Peto, R, British Medical fournal, 1977, 1, 1433.

${ }^{28}$ Hayes, W L, in Statistics, p 280 . London, Holt Rinehart and Winston, 1969.
${ }^{29}$ Grant, C J, Powell, J N, and Radford, S G, British fournal of Anaesthesia, 1974, 46, 653.

${ }^{30}$ Amess, J A L, et al, Lancet, 1978, 2, 339.

${ }^{31}$ Corbett, T H, Annals of the New York Academy of Sciences, 1976, 271, 58.

${ }^{32}$ Thompson, J M, The Chemical Engineer. In press.

${ }^{33}$ Tomlin, P J, and Gjessing, J, Canadian Anaesthetists' Society fournal, $1978,25,412$.

${ }^{34}$ Lancet, 1972, 2, 519.

(Accepted 26 fanuary 1979)

\title{
Occult aortic stenosis as cause of intractable heart failure
}

\author{
D J R MORGAN, R J C HALL
}

British Medical fournal, 1979, 1, 784-787

\section{Summary and conclusions}

During a three-year period 10 patients with critical aortic stenosis were referred to a cardiac referral centre with symptoms and signs of intractable cardiac failure and low cardiac output. In nine patients the correct diagnosis was not suspected at the referring hospital, and in the remaining patient the true severity of the aortic stenosis was not appreciated and cardiomyopathy was suggested as an additional diagnosis. The most common referral diagnoses were severe mitral regurgitation (four patients), congestive cardiomyopathy (two patients), or both (three patients). Only two patients had soft ejection systolic murmurs at the base of the heart radiating into the neck, and such a murmur appeared in a third patient during medical treatment. The carotid pulses were of small volume but the characteristic slow-rising, anacrotic nature of the pulse could not be appreciated clinically. The diagnosis was suspected in nine patients because of aortic valve calcification detected by lateral chest $\boldsymbol{x}$-ray examination in seven patients and by $x$-ray screening of the heart in two, and because of abnormal aortic valve echoes in the echocardiogram of all five patients in whom the aortic valve could be seen. Eight patients underwent aortic valve replacement despite seemingly poor preoperative left ventricular function. Three patients died, of whom two had severe coexistent coronary artery disease. The five survivors all returned to normal lives and needed little or no medication.

Critical aortic stenosis should be actively sought in patients with severe heart failure of unknown cause since surgery may enable them to resume their normal lives.

\section{Introduction}

Aortic valve stenosis is usually easily recognised on the basis of well-established and characteristic symptoms and physical signs, and surgical treatment now achieves satisfactory results with low mortality. ${ }^{1-3}$ Recognising aortic stenosis clinically and assessing its severity may become difficult if left ventricular

Cardiac Department, Brompton Hospital, London SW3 6HP

D J R MORGAN, MB, senior house officer

R J C HALL, MB, MRCP, senior registrar (present appointment: consultant cardiologist, Royal Victoria Infirmary, Newcastle upon Tyne)

dysfunction supervenes. As cardiac output falls and the flow across the stenosed valve decreases the characteristic murmur becomes softer or disappears, the slow-rising pulse is more difficult to appreciate, and the clinical picture becomes that of low cardiac output with pulmonary oedema and heart failure.

We report on a series of 10 patients who presented with severe heart failure refractory to medical treatment and in whom the correct diagnosis of critical aortic stenosis was not suspected at the referring hospital. We present these cases to emphasise the features that led to the correct diagnosis being suspected.

Patients, methods, and results

CLINICAL PRESENTATION

Table I shows the clinical features of the 10 patients studied, who presented at this hospital between 1974 and 1977. In only one patient (case 6) was the true diagnosis suspected at the referring hospital, and even then a superadded cardiomyopathy was suggested as the signs of obstruction of the left ventricular outflow tract were not impressive. The remaining patients were referred as cardiac failure of unknown cause. Mitral regurgitation alone (four patients) or in association with cardiomyopathy (three patients) was the most commonly suspected underlying cause of the cardiac failure. This was because these patients had apical systolic murmurs, which in several cases may have been due to functional mitral regurgitation since in four this was subsequently shown at cardiac catheterisation. In two patients congestive cardiomyopathy alone was suspected. All patients had severe (New York Heart Association (NYHA) grade IV) symptoms, evidence of reduced cardiac output with a small carotid pulse, and a cool periphery despite intensive medical treatment. Three patients had a soft ejection systolic murmur, best heard at the base and radiating into the neck; in one of these patients this appeared during medical treatment.

\section{INVESTIGATIONS}

ECG (table I)-The ECG in five patients showed increased QRS voltage, depressed ST segments, and lateral T-wave inversion, which suggested the possibility of aortic stenosis. The changes in the other patients were non-specific, although in three cases there was impaired conduction (left bundle-branch block, left bundle-branch block with first-degree heart block, and left axis deviation with first-degree heart block).

Chest $x$-ray examination-Posteroanterior chest $x$-ray films showed cardiomegaly and pulmonary oedema in all patients. Lateral chest $x$ ray films suggested aortic valve calcification in seven patients (table I), which was confirmed by screening using a high-resolution caesiumiodide image intensifier (CGR). Screening also showed aortic valve calcification in two patients in whom it was not detected on the lateral chest $x$-ray film. The one patient in whom aortic valve calcification was not detected also had non-specific ECG changes (case 4).

Echocardiography-An M-mode echocardiogram was obtained in six patients. This showed an enlarged left ventricular cavity with poor 
TABLE I-Clinical details of the 10 patients studied, with results of electrocardiography, chest $x$-ray examination, screening, and catheterisation

\begin{tabular}{|c|c|c|c|c|c|c|c|c|c|c|}
\hline \multirow{2}{*}{$\begin{array}{l}\text { Case } \\
\text { No }\end{array}$} & \multirow[b]{2}{*}{$\begin{array}{l}\text { Age } \\
\text { and } \\
\text { sex }\end{array}$} & \multirow{2}{*}{ Initial diagnosis } & \multirow{2}{*}{ Symptoms } & \multirow{2}{*}{ ECG } & \multicolumn{2}{|c|}{$\begin{array}{l}\text { Evidence of aortic } \\
\text { valve calcification }\end{array}$} & \multicolumn{3}{|c|}{ Catheterisation } & \multirow{2}{*}{ Outcome } \\
\hline & & & & & $\begin{array}{l}\text { Chest } \\
x \text {-ray }\end{array}$ & $\begin{array}{l}\text { Screen- } \\
\text { ing }\end{array}$ & $\begin{array}{c}\text { Aortic } \\
\text { gradient } \\
(\mathrm{mm} \mathrm{Hg})\end{array}$ & $\begin{array}{c}\text { Cardiac } \\
\text { index } \\
\left(1 / \mathrm{min} / \mathrm{m}^{2}\right)\end{array}$ & $\begin{array}{l}\text { Other } \\
\text { findings }\end{array}$ & \\
\hline 1 & $53, \mathrm{~F}$ & Mitral regurgitation & $\begin{array}{l}3 \text { months' dyspnoea, } \\
\text { paroxysmal } \\
\text { nocturnal } \\
\text { dyspnoea, and } \\
\text { oedema }\end{array}$ & $\begin{array}{l}\text { Sinus rhythm, left } \\
\text { ventricular } \\
\text { hypertrophy }\end{array}$ & $?+$ & + & 75 & $1 \cdot 1$ & $\begin{array}{l}\text { Mitral } \\
\text { regurgitation }\end{array}$ & $\begin{array}{l}\text { Aortic valve replacement, } \\
\text { uncomplicated. } \\
\text { Returned to work }\end{array}$ \\
\hline $2 *$ & $65, \mathrm{~F}$ & Congestive cardiomyopathy & $\begin{array}{l}6 \text { months' increasing } \\
\text { dyspnoea, angina, } \\
\text { and oedema }\end{array}$ & $\begin{array}{l}\text { Sinus rhythm, left } \\
\text { bundle-branch block }\end{array}$ & - & + & 40 & 1.5 & $\begin{array}{l}\text { Mild aortic } \\
\text { and mitral } \\
\text { regurgitation }\end{array}$ & $\begin{array}{l}\text { Aortic valve replacement, } \\
\text { after which left } \\
\text { ventricular function } \\
\text { good. Aortic root } \\
\text { damage. Died during } \\
\text { operation }\end{array}$ \\
\hline 3 & $71, \mathrm{~F}$ & $\begin{array}{l}\text { Mitral regurgitation, } \\
\text { congestive } \\
\text { cardiomyopathy }\end{array}$ & $\begin{array}{l}3 \text { months' increasing } \\
\text { dyspnoea and } \\
\text { oedema }\end{array}$ & $\begin{array}{l}\text { Sinus rhythm, left } \\
\text { ventricular } \\
\text { hypertrophy }\end{array}$ & $?+$ & + & & & & $\begin{array}{l}\text { Aortic valve replacement, } \\
\text { uncomplicated. } \\
\text { Resumed normal } \\
\text { activity }\end{array}$ \\
\hline 4 & $75, \mathrm{~F}$ & Mitral regurgitation & Increasing dyspnoea & Atrial fibrillation & - & - & 80 & $1 \cdot 3$ & $\begin{array}{l}\text { Mitral } \\
\text { regurgitation }\end{array}$ & $\begin{array}{l}\text { Aortic valve replacement } \\
\text { and mitral plication. } \\
\text { Failed to come of } \\
\text { bypass and died during } \\
\text { operation. Severe } \\
\text { ischaemic heart disease }\end{array}$ \\
\hline 5 & $71, \mathrm{~F}$ & $\begin{array}{l}\text { Mitral regurgitation, } \\
\text { ? aortic regurgitation }\end{array}$ & $\begin{array}{l}\text { Increasing dyspnoea } \\
\text { and bronchitis }\end{array}$ & Atrial fibrillation & + & + & 70 & $1 \cdot 6$ & $\begin{array}{l}\text { Mild mitral } \\
\text { regurgitation }\end{array}$ & $\begin{array}{l}\text { Refused operation. } \\
\text { Died of cardiac failure } \\
6 \text { months later }\end{array}$ \\
\hline 6 & $46, M$ & $\begin{array}{l}\text { Aortic stenosis, } \\
\text { ? severity, } \\
\text { ? cardiomyopathy }\end{array}$ & $\begin{array}{l}3 \text { months' increasing } \\
\text { dyspnoea and } \\
\text { paroxysmal } \\
\text { nocturnal dyspnoea }\end{array}$ & $\begin{array}{l}\text { Sinus rhythm, left } \\
\text { ventricular strain. } \\
\text { Poor R-wave } \\
\text { progression in leads } \\
\text { V1-V4 }\end{array}$ & + & + & 40 & 1.5 & & $\begin{array}{l}\text { Aortic valve replacement, } \\
\text { uncomplicated. } \\
\text { Returned to full } \\
\text { normal work }\end{array}$ \\
\hline 7 & $63, M$ & $\begin{array}{l}\text { Mitral regurgitation, } \\
\text { congestive } \\
\text { cardiomyopathy }\end{array}$ & $\begin{array}{l}\text { Recurrent pulmonary } \\
\text { oedema, angina }\end{array}$ & Atrial fibrillation & $?+$ & + & 60 & $2 \cdot 3$ & $\begin{array}{l}\text { Normal mitral } \\
\text { valve, normal } \\
\text { coronary }\end{array}$ & $\begin{array}{l}\text { Aortic valve replacement, } \\
\text { uncomplicated. } \\
\text { Returned to full-time } \\
\text { work }\end{array}$ \\
\hline 8 & $69, M$ & Mitral regurgitation & Increasing dyspnoea & $\begin{array}{l}\text { Sinus rhythm, P-R } \\
\text { interval } 0.24 \mathrm{~s} \text {, left } \\
\text { bundle-branch block }\end{array}$ & + & + & 70 & & & $\begin{array}{l}\text { Aortic valve replacement, } \\
\text { uncomplicated. } \\
\text { Resumed normal life }\end{array}$ \\
\hline 9 & $64, M$ & $\begin{array}{l}\text { Mitral regurgitation, } \\
\text { congestive } \\
\text { cardiomyopathy }\end{array}$ & $\begin{array}{l}\text { Increasing dyspnoea, } \\
\text { angina }\end{array}$ & $\begin{array}{l}\text { Sinus rhythm, left } \\
\text { ventricular } \\
\text { hypertrophy }\end{array}$ & + & + & 40 & & $\begin{array}{l}\text { Coronary } \\
\text { artery disease }\end{array}$ & $\begin{array}{l}\text { Operation declined. } \\
\text { Patient lost to } \\
\text { follow-up }\end{array}$ \\
\hline 10 & $57, \mathrm{~F}$ & Congestive cardiomyopathy & Dyspnoea & $\begin{array}{l}\text { Sinus rhythm, P-R } \\
\text { interval } 0 \cdot 24 \mathrm{~s} \text {, left } \\
\text { axis deviation }\end{array}$ & - & + & 60 & 1.0 & & $\begin{array}{l}\text { Aortic valve replacement. } \\
\text { Died of low output } \\
10 \text { days later. Severe } \\
\text { ischaemic heart disease }\end{array}$ \\
\hline
\end{tabular}

*This patient had had two episodes of subacute bacterial endocarditis six and 20 years previously and an operation to close a ruptured sinus of Valsalva.

septal and posterior-wall excursion. In all paticnts the interventricular septum was abnormally thick (mean ( \pm 1 SD) septal thickness $15 \cdot 8 \pm 2 \cdot 7 \mathrm{~mm}$; normal $<12 \mathrm{~mm})$. The left ventricular posterior wall was of normal thickness in all patients. In five of the six patients abnormal echoes were detected in the aortic valve, and in the other patient the aortic valve was not seen for technical reasons. The echocardiographic features of these six patients were compared with the findings in 10 consecutive patients who presented with cardiac failure resulting from proved congestive cardiomyopathy (table II), since this is an important differential diagnosis and some of our patients were mistakenly thought before referral to have congestive cardiomyopathy. Table II also includes results from 15 normal subjects for comparison.

Cardiac catheterisation-Nine of the 10 patients were catheterised (table I). In seven this was to confirm aortic stenosis suspected from the results of the ECG, lateral chest $x$-ray examination, screening, and echocardiography; but before catheterisation the remaining two patients (cases 1 and 7 ) were incorrectly thought to have mitral regurgitation with slight aortic disease. In all patients the ejection fraction was under $30 \%$. There were no complications.

TABLE II-Mean $( \pm S D)$ echocardiographic findings in six patients with occult aortic stenosis in present series compared with findings in 15 normal adults and 10 consecutive patients with proved congestive cardiomyopathy and heart failure

\begin{tabular}{|c|c|c|c|c|}
\hline & $\begin{array}{c}\text { Septal } \\
\text { thickness } \\
(\mathrm{mm})\end{array}$ & $\begin{array}{c}\text { Thickness } \\
\text { of } \\
\text { posterior } \\
\text { wall } \\
\text { of LV } \\
(\mathrm{mm})\end{array}$ & $\begin{array}{l}\text { End- } \\
\text { systolic } \\
\text { dimension } \\
\text { of LV } \\
\text { (cm) }\end{array}$ & $\begin{array}{l}\text { End- } \\
\text { diastolic } \\
\text { dimension } \\
\text { of LV } \\
\text { (cm) }\end{array}$ \\
\hline Normal subjects $(n=15)$ & $8.5 \pm 1.7$ & $8 \cdot 0 \div 2 \cdot 0$ & $3.0 \pm 0.7$ & $4 \cdot 6 \pm 0.6$ \\
\hline $\begin{array}{c}\text { Patients with occult aortic stenosis } \\
(n=6)\end{array}$ & $15 \cdot 8 \pm 2 \cdot 7$ & $9 \cdot 2 \pm 2 \cdot 3$ & $5.5 \pm 0.67$ & $6.5 \pm 0.97$ \\
\hline $\begin{array}{l}\text { Patients with congestive cardiomyo- } \\
\text { pathy }(\mathrm{n}=10)\end{array}$ & $7 \cdot 7 \pm 1 \cdot 4$ & $7 \cdot 4 \pm 1 \cdot 6$ & $5 \cdot 1 \pm 0 \cdot 58$ & $6.3 \pm 0.50$ \\
\hline Significance* & $P<0.001$ & NS & NS & NS \\
\hline
\end{tabular}

LV = Left ventricle. NS = Not significant.

*Significance of difference between patients with occult aortic stenosis and those with * Significance of difference between patients with
congestive cardiomyopathy (Student's $t$ test).

\section{SURGICAL RESULTS}

Surgery was offered to all 10 patients and refused by two. Of these two, one died within six months of progressive heart failure and the other was discharged, still in heart failure, and lost to follow-up. Thus aortic valve replacement was performed in eight patients. Three early deaths (38\% mortality) and no late deaths occurred. Two of the patients who died had severe coincident coronary artery disease; one would not come off bypass and one died 10 days later of low cardiac output. The third patient who died (case 2 ) had had previous subacute bacterial endocarditis in the region of the aortic valve and surgical closure of a ruptured sinus of Valsalva. Although the valve was replaced and the left ventricle functioned well after the aortic stenosis had been relieved, the aortic root could not be repaired and the patient died during the operation. Two of the surviving patients had normal coronary arteries; the state of the coronary artery was unknown in the other three survivors. All patients received mechanical prosthetic valves (four Starr-Edwards, four Bjork-Shiley).

\section{FOLLOW-UP}

All patients who survived surgery were reviewed six months to two and a half years postoperatively. All had returned to normal activities, were NYHA class I or II, and were receiving minimal medication. Therefore from the clinical point of view left ventricular function had recovered in the survivors. Functional mitral regurgitation disappeared in all patients. The size of the heart as assessed from the posteroanterior chest $x$-ray film decreased in all patients and became normal in three (fig 1). Echocardiograms could be obtained in only three of the five survivors (cases 3,6 , and 8 ), since in one patient the follow-up study was unsatisfactory and one patient refused to attend. All showed that the dimensions of the left ventricle were returning towards normal but increased septal thickness persisted.

\section{CASE REPORT (CASE 3)}

This 71-year-old woman was referred from another hospital for investigation of recurrent bilateral pleural effusions. Four years before 
she had suffered an unexplained syncopal attack, after which she developed angina and exertional dyspnoea. These were treated medically. A systolic murmur noticed at this time was not thought to be important. Three months before referral she became much more dyspnoeic and developed peripheral oedema. On examination she had a sinus tachycardia, small-volume pulse, cool periphery, raised jugular venous pressure, apical gallop, soft apical pansystolic murmur, bilateral pleural effusion, and peripheral oedema. The chest $x$-ray

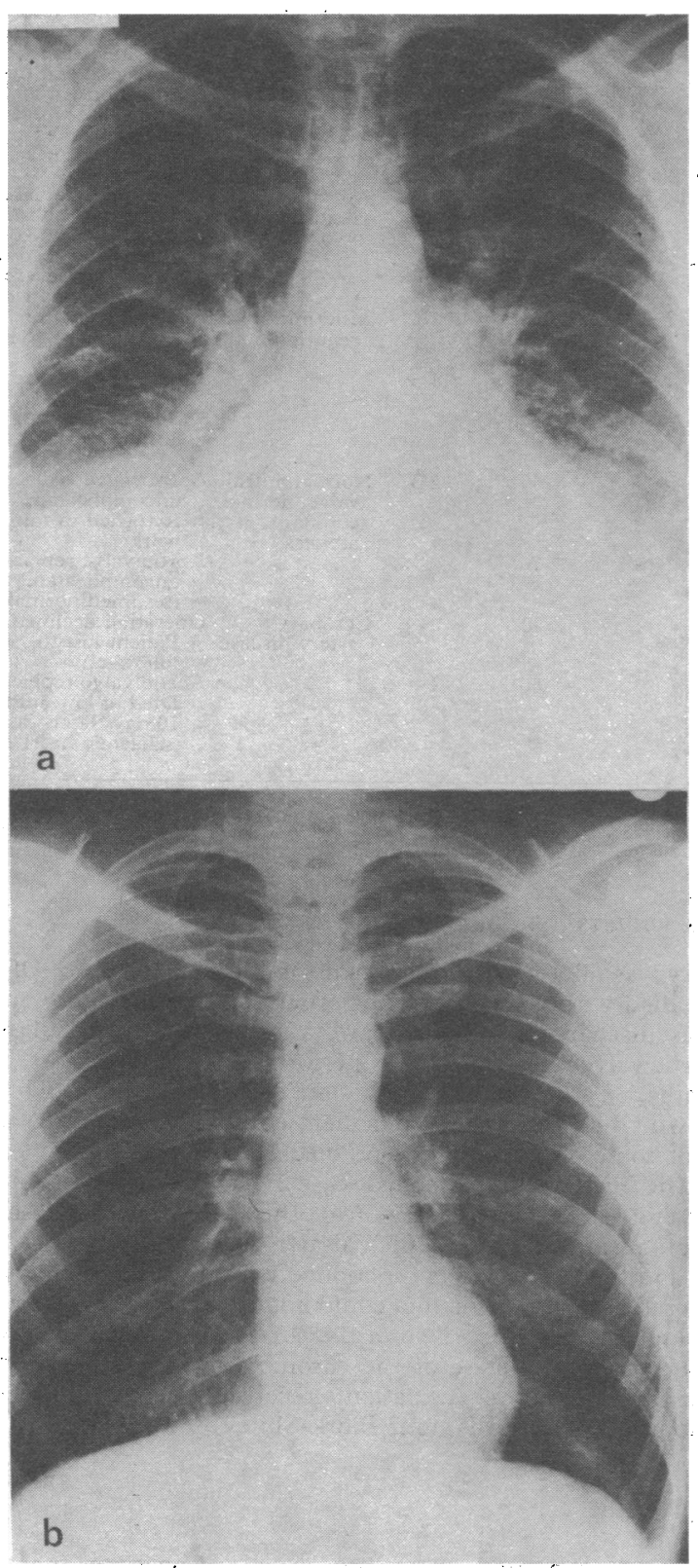

FIG 1 -Case 6 . Chest $x$-ray films before $(a)$ and one year after $(b)$ aortic valve replacement.

film showed cardiomegaly, bilateral pleural effusions, pulmonary oedema, and possible aortic valve calcification, which.was confirmed by screening. The echocardiogram (fig 2) showed a dilated left ventricular cavity with poor movement of the posterior wall, a thickened interventricular septum, and multiple echoes from the aortic valve region. Screening of the valve confirmed severe valve calcification. Cardiac catheterisation was not performed, and at operation a heavily calcified, severely stenotic aortic valve was replaced. Postoperative recovery was uneventful, and the patient returned to normal activity taking a small dose of diuretic. Follow-up echocardiograms showed that the size of the ventricular cavity was decreasing, and excursion of the left ventricular posterior wall improved.

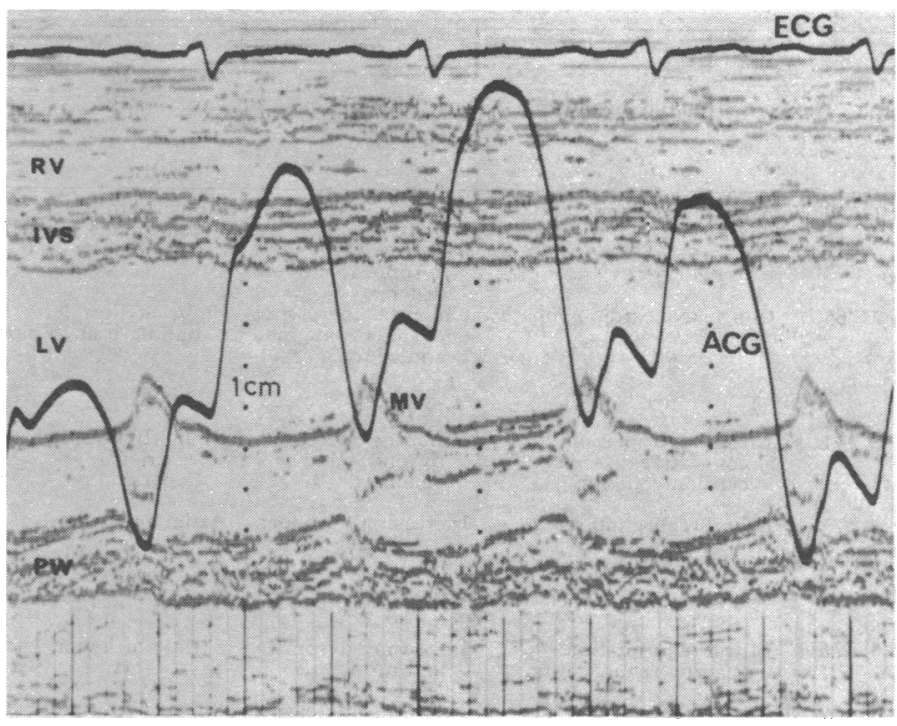

FIG 2-Case 3. M-mode echocardiogram of left ventricle before surgery Left ventricular cavity is entarged $(6.5 \mathrm{~cm}$; upper limit of normal $5.8 \mathrm{~cm}$ ) and interventricular septum thickened (17 mm; upper limit of normal $12 \mathrm{~mm}$ ).

$\mathbf{R V}=$ Right ventricle. IVS $=$ Interventricular septum. $L V=$ Left ventricle. $P W=$ Posterior wall of left ventricle. $M V=$ Mitral valve. $A C G=A$ pex cardiogram.

\section{Discussion}

Patients with persistent cardiac failure refractory to intensive medical treatment present a diagnostic challenge to the physician. Those patients in whom a surgically treatable cause is possible should be identified so that they may be referred for further assessment and surgery. The present series shows that critical aortic stenosis is one such cause and that even when the patient reaches a referral centre the diagnosis may be difficult. The cases were specifically those in which the referral diagnosis was not aortic stenosis and the characteristic physical signs of aortic stenosis were absent or slight. They were collected over three years at a specialist referral centre, and hence the condition is relatively uncommon. During this time many other patients with aortic stenosis, pulmonary oedema, and impaired left ventricular function were treated, but in these the diagnosis was still easily appreciated on clinical examination.

As left ventricular failure occurs and cardiac output falls the two clinical features most important for making the correct diagnosis-namely, the harsh systolic murmur at the base and the slow-rising anacrotic carotid pulse-become less obvious. This is easily explained since the murmur becomes quieter as less. blood flows across the narrowed aortic valve, and as the cardiac output becomes less so the carotid pulse becomes increasingly difficult to palpate or record and hence its characteristic slow upstroke is hard to detect clinically.

Occult aortic stenosis causes low cardiac output and cardiac failure. ${ }^{5}$ The present series emphasises this and allows two important questions to be examined. Firstly, what clinical and non-invasive features suggest the presence of occult aortic stenosis, and, secondly, is surgery worth while in such critically ill patients?

The diagnosis should be suspected in any patient with persistent heart failure of unknown aetiology in whom there is a basal systolic murmur, however soft, radiating into the neck (three patients in this series). Such a murmur may reappear during medical treatment, presumably because cardiac output has improved (case 2). The clinical picture may be dominated by functional mitral regurgitation due to left ventricular dilatation when the principal lesion is aortic stenosis, and clues suggesting aortic valve disease such as valve calcification seen on the chest $x$-ray film and abnormal aortic echoes should not be ignored. The two most useful non-invasive investigations are lateral 
chest $x$-ray examination, which together with screening of the aortic valve with a high-resolution caesium-iodide image intensifier identified $90^{\circ}{ }_{0}$ of the patients, and echocardiographic examination of the aortic valve, which disclosed abnormal echoes from the valve in all five patients in whom the valve was seen. It is therefore mandatory to carry out lateral chest $x$-ray examinations in patients with heart failure of unknown origin and to proceed to screening if the film does not show aortic valve calcification. The heart may be satisfactorily screened for calcification with equipment available in most general hospitals.

ECG evidence of left ventricular hypertrophy or strain, although occurring in patients with other conditions-for example, those with cardiomyopathy or end-stage hypertension -is also a clue to the diagnosis, but, more importantly, lack of such evidence must not be regarded as excluding the diagnosis. The echocardiogram as well as being helpful is also potentially misleading. The left ventricle was invariably dilated and showed poor contraction, which is also the case in congestive cardiomyopathy (table II), and in fact in two patients these echocardiographic appearances had led to the mistaken diagnosis of congestive cardiomyopathy being made at the referring hospital. More careful inspection, however, usually allows this mistake to be avoided, since in all patients with congestive cardiomyopathy the interventricular septum was of normal or less than normal thickness whereas it was thickened in all patients with aortic stenosis. This distinction is particularly important as echocardiography becomes more widespread as a screening investigation in general hospitals.

Once the true diagnosis has been established the important question is whether such diagnostic efforts are rewarded by acceptable results of surgery. Previous studies have shown that aortic valve replacement in patients with good left ventricular function has a mortality of about $5 \%{ }^{1-3}$ and that good results may be obtained even when left ventricular function is compromised. ${ }^{4}$ The present series is the only one reported in which all the patients had initially unsuspected aortic stenosis. In view of the extremely poor preoperative state, left ventricular function, and long-term outlook of these patients the mortality of $38 \%$ is acceptable, particularly as all five survivors returned to normal lives. Interestingly, two of the three patients who died had severe coexistent coronary artery disease, which others have found may make the operation hazardous. ${ }^{45}$

These cases emphasise that occult aortic stenosis should be suspected in all patients with severe cardiac failure of unknown aetiology; that lateral chest $x$-ray examination, screening of the heart for aortic valve calcification, and echocardiographic inspection of the aortic valve may all provide clues to the diagnosis; and that even in patients in their 70 s and 80 s satisfactory surgical results may be obtained despite seemingly poor preoperative left ventricular function.

We thank Dr R Gibson, Dr M Honey, Dr D Gibson, Mr M Paneth, Mr S Lennox, and Mr C Lincoln for permission to report these cases.

Requests for reprints should be addressed to Dr R J C Hall, Royal Victoria Infirmary, Newcastle upon Tyne NE1 4LP.

\section{References}

${ }^{1}$ Boncheck, L I, and Starr, A, American fournal of Cardiology, 1975, 35, 843.

2 Henze, A, Carlsson, S, and Bjork, V O, Scandinavian fournal of Thoracic and Cardiovascular Surgery, 1973, 7, 17.

${ }^{3}$ Wallace, R B, American fournal of Cardiology, 1975, 35, 866.

${ }^{4}$ Smith, N, McAnulty, J H, and Rahimtoola, S H, Circulation, 1978, 58, 255.

${ }^{5}$ Croke, R P, et al, Annals of Thoracic Surgery, 1977, 24, 38.

(Accepted 29 fanuary 1979)
University of Southampton, Southampton SO9 $4 X Y$

$M$ GRIFFITHS, BA, formerly research fellow in community medicine W E WATERS, $M B, F F C M$, professor of community medicine E D ACHESON, DM, FRCP, professor of clinical epidemiology influence in determining the mean postoperative stay than does the individual consultant.

\section{Introduction}

We chose to study patients undergoing elective inguinal herniorrhaphy as this is a relatively standard surgical procedure that nevertheless produces a considerable variation in the duration of postoperative stay and sickness absence. The postoperative stay varies between hospitals ${ }^{1}$ and consultants, ${ }^{2}$ but the possible interaction between these two factors requires further study. Inguinal hernia is common; the diagnosis is certain or easily disproved at operation; operation is the treatment of choice; and the condition is accompanied by a low mortality. Semmence ${ }^{1}$ investigated various factors associated with inguinal herniorrhaphy at two teaching hospitals. The present study included different types of hospitals and several consultants who operated at more than one hospital.

\section{Patients and methods}

We studied men aged 16-65 inclusive who were admitted to eight hospitals in Wessex for elective repair of an inguinal hernia during 